\title{
PETANI DAN POLITIK: STUDI PREFERENSI POLITIK PETANI IJEN BONDOWOSO
}

\author{
Rony Zamzam Firdaus, Hary Yuswadi, Raudlatul Jannah
}

Sosiologi, FISIP, Universitas Jember

ronyzamzamf7@gmail.com

\begin{abstract}
This study aims to explain about political preferences and the peasant community, especially in the Curah Macan, Kalianyar Village, Ijen District, Bondowoso Regency East Java. Most of them are Horticulture farmers who use Plantation and Perhutani land. Ijen's Farmers are often produced cabbage and potatoes. When these two crops have been harvested, it sold to the market, eaten for daily necessities, and there are also some crops that are dried in the sun and reprocessed into new seeds. This research focuses on the peasant and politics which included political affiliation and land tenure in the countryside. The historical impact of land tenure on citizens has an effect on rural political change. Land tenure and subsequent policies such as land leasing, marketing, distribution of plant seeds are related to the political system that occurs in the bulk Macan hamlet and the political life of the community. For this reason, the study use Robert W. Hefner's theory of Tengger. It explains farmers and rural politics. The research method is qualitative research methods.
\end{abstract}

Keywords: farmers, preference of politics, agrarian society, rural area

\begin{abstract}
Abstrak
Penelitian ini berfokus pada preferensi politik petani sayur di Dusun Curah Macan, Desa Kalianyar, Kecamatan Ijen, Kabupaten Bondowoso, Jawa Timur. Umumnya petani menanam di lahan Perkebunan dan Perhutani. Petani menanam kubis dan kentang. Penelitian ini menjelaskan tentang petani dan politik yang meliputi afiliasi politik dan penguasaan lahan di pedesaan. Dampak sejarah penguasaan lahan ke warga berpengaruh terhadap perubahan politik pedesaan. Penguasaan lahan dan kebijakan-kebijakan setelahnya seperti sewa lahan, pemasaran, pembagian bibit tanaman memiliki keterkaitan dengan sistem politik yang terjadi di dusun Curah Macan serta kehidupan politik masyarakat. Penelitian ini menggunakan rujukan pengalaman Robert W. Hefner di Tengger yang menjelaskan tentang realitas masyarakat yang mengacu pada petani dan politik di pedesaan. Metode penelitian dalam tulisan ini adalah metode penelitian kualitatif.
\end{abstract}

Kata Kunci: petani, preferensi politik, masyarakat agraris, pedesaan 


\section{PENDAHULUAN}

Perubahan ekonomi merupakan suatu proses moral sekaligus material. Tidak bisa dipungkiri bahwa dampaknya sangat terasa. Tidak hanya berdampak dari segi pendapatan dan produksi, tapi juga pada segi identitas, aspirasi, serta otoritas. Di negara-negara Barat yang rata-rata sudah modern, pertumbuhan kapitalisme telah membuat nilai-nilai tradisional menjadi semakin terkikis di dalamnya. Seperti apa yang dinyatakan oleh Hefner (1999) bahwa masyarakat tradisional dengan struktur serta kebutuhan yang lebih stabil harus memberi jalan kepada suatu dunia dimana identitas dan selera senantiasa berubah sesuai dengan kepentingan produksi dan status. Di era sekarang tentu perkembangan ini tidak hanya terjadi di dunia Barat saja. Seiring dengan berjalannya waktu perubahan yang terjadi mulai merata hampir di seluruh dunia.

Seperti halnya pola pikir masyarakat yang semakin hari semakin berkembang. Tentunya hal ini tidak lepas dari perkembangan zaman. Tidak hanya masyarakat di wilayah kota yang pola pikirnya berkembang, kali ini masyarakat yang tinggal di desa pun juga pola pikirnya berubah. Pada masa sekarang, masyarakat yang tinggal di desa rata-rata juga sudah mempunyai pemikiran maju. Maju dalam pengertian bahwa setidaknya ketika mereka bertani di sawah, hasil pertanian mereka selain dijual juga bisa diolah kembali menjadi bibit dan kemudian ditanami kembali agar dapat memperoleh hasil yang lebih banyak. Pola pertanian seperti ini sekarang juga tidak hanya pada petani golongan tua, tapi juga golongan muda atau para pemuda juga terkadang ikut serta dalam bertani dengan cara seperti ini. Hal ini menandakan bahwa regenerasi dalam masyarakat pedesaan khususnya yang bermata pencaharian sebagai petani juga terjadi demi keberlangsungan hidup mereka. Selain cara bertani, tidak jarang juga para petani menjual hasil taninya kepada kelompok-kelompok yang dianggap dapat memberikan keuntungan dan hasil yang diinginkan petani.

Akan tetapi, terkadang hasil atau upah yang didapatkan oleh para petani tidak sesuai harapan mereka. Banyak faktor yang membuat hal tersebut bisa terjadi salah satunya dari kualitas hasil pertanian. Jika hasil pertanian tersebut sebelum panen terkena serangan hama atau semacamnya, maka kualitas dari hasil pertanian tersebut pun juga akan ikut menurun. Hal inilah yang kemudian membuat kelompok-kelompok seperti tengkulak kemudian memberikan harga yang murah kepada petani karena menyesuaikan dengan kualitas hasil pertaniannya. Petani pun tidak bisa membantah. Mereka tetap harus menerimanya meskipun hal tersebut juga menimbulkan kerugian yang cukup besar terhadap mereka.

Sementara itu, golongan petani juga tidak menutup kemungkinan untuk bertani dengan melaksanakan aturan yang dicanangkan oleh instansi atau lembaga tertentu. Misalnya jika lahan yang digunakan oleh petani untuk bertani merupakan lahan milik negara, maka mereka diharuskan untuk mematuhi aturan yang diberikan oleh lembaga tersebut. Tentunya jika hal tersebut tidak dipatuhi oleh petani maka mereka tidak mendapatkan izin untuk bertani di lahan itu. Hal ini senada dengan beberapa referensi yang menceritakan situasi dan 
kondisi petani di Jawa. Sebagai kelompok masyarakat yang memproduksi pangan, mereka mengatakan bahwa petani selalu berada di bawah kendali secara politik, ekonomi dan sosial dari kelompok non petani.

Berawal dari kekuasaan raja pada jaman feodal, lalu kekuasaan kolonial, hingga kewenangan organisasi perdagangan dunia (WTO), kekuatan kapital yang dimiliki sebagian kecil pengusaha mendominasi arah dan kebijakan organisasi produksi usaha tani petani-petani produsen. Kebijakankebijakan tersebut mengarah pada terciptanya kondisi yang menyebabkan golongan mayoritas petani menjauh dari penguasaan sumber produksi, termasuk tenaganya sendiri, dan memperlemah kemampuan mereka untuk berproduksi secara mandiri. Pada kenyataannya memang banyak yang mengalami hal seperti itu. Bantuan dari pemerintah tentu menjadi salah satu alternatif dalam mengatasi permasalahan yang dihadapi oleh para petani saat ini. Apalagi sekarang sudah masuk masa dimana berbagai penyuluhan maupun bantuan hadir dalam masyarakat petani. Masa ini disebut sebagai masa politik, pesta demokrasi. Pesta dimana sang calon pemimpin berusaha untuk menarik simpati rakyat melalui janji-janji atau berupa bantuan bahan pokokyang mereka berikan kepada rakyat. Tentunya hal ini dilakukan berdasarkan kepentingan semata-mata untuk mengejar kekuasaan menjadi seorang pemimpin.

Sosok pemimpin di mata masyarakat tentunya harus bisa setidaknya mewujudkan apa yang diinginkan serta mampu menjawab hal-hal yang dikeluhkan oleh masyarakat. Untuk mewujudkan keinginan dari masyarakat tersebut, menurut Sastroatmodjo (1995), norma atau kaidah yang mengatur berbagai kegiatan bersama dalam rangka menempatkan dirinya ditengah-tengah masyarakat sangat diperlukan agar keadilan dalam berpolitik senantiasa dapat ditegakkan. Atas dasar itulah kemudian untuk menegakkan norma tersebut dibutuhkan adanya lembaga pemerintah yang memiliki otoritas tertentu agar norma-norma yang ada dapat ditaati.

Selain itu, politik juga memiliki keterkaitan dengan berbagai kelompok termasuk partai politik dan kegiatan perseorangan (individu). (Lihat Miriam Budiardjo, 1992: 8). Seperti apa yang dinyatakan oleh Zainudin (dalam Zainudin, 1996: 3) masyarakat mengartikanbahwapolitikitumerupakan sebuah tindakan yang tidak sesuai dengan nilai-nilai moral. Politik dilihat sebagai sebuah ajang dimana seseorang memberikanjanji-janji yang pada awalnya dikatakan akan segera dipenuhi, padahal sebetulnya janji-janji tersebut belum tentu akan dipenuhi oleh mereka. Janjijanji tesebut sebenarnya lebih banyak memberikan kesan yang negatif bagi para pendengarnya. Namun, hal tersebut seringkali dilakukan dan juga termasuk dalam bagian perilaku politik. Interaksi antara pemerintah dan masyarakat, antar lembaga pemerintah dan antar kelompok dan individu dalam masyarakat dalam rangka proses pembuatan, pelaksanaan dan penegakkan keputusan politik pada dasarnya merupakan perilaku politik. Dari perilaku politik tersebut kemudian memunculkan sebuah sikap dalam masyarakat yang kemudian dikenal sebagai sikap politik. Sikap politik ini 
kemudian menjadi penting terkait dengan pengaruhnya terhadap terbentuknya perilaku pemilih dalam masyarakat.

Aspek geografis juga mempunyai hubungan dengan perilaku pemilih. Menurut Zainudin (1996: 48-49) Rasa kedaerahan mempunyai pengaruh yang cukup kuat dalam terciptanya dukungan seseorang terhadap partai. Di beberapa wilayah tertentu, loyalitas terhadap partai politik seakan-akan bukan menjadi hal yang asing lagi. Tentu saja hal ini erat kaitannya dengan status sosial dan ekonomi seseorang. Namun berdasarkan penelitian yang dilakukan oleh Afan Gaffar menunjukkan bahwa status sosial dan ekonomi seseorang tidak terlalu memiliki pengaruh yang cukup besar terhadap perilaku pemilih di Indonesia. Nyaris tidak ada perbedaan dalam sikap politik mereka baik dalam kategori orang kaya maupun orang miskin; antara orang yang memiliki tanah yang luas dengan orang yang memiliki tanah sedikit; antara orang yang memiliki pekerjaan sebagai pedagang dengan buruh tani, dan lain sebagainya.

Sementara itu, melihat dari topik yang dibahas mengenai politik petani, ada beberapa temuan atau penelitian terdahulu yang mempunyai pokok bahasan yang hampir mirip. Sebut saja Skripsi milik Sandra Tiffany C. R. yang berjudul "Preferensi Politik (Studi Tentang Perilaku Pemilih di Lingkungan IV Kelurahan Perkebunan Sipare-Pare pada Pemilihan Kepala Daerah (Bupati) Tahun 2008". Penelitian ini menjelaskan tentang bagaimana perilaku pemilih telah menjadi pembahasan yang sangat menarik di dalam proses demokrasi terutama di dalam Pemilihan umum. Dalam penelitian ini dijelaskan bahwa rakyat ditempatkan sebagai hakim tertinggi dalam menentukan calon Presiden, Wakil Presiden, Kepala Daerah dan Wakil Kepala Daerah yang dilakukan secara langsung. Hal ini tentu saja berkaitan dengan tujuan membangun suatu masyarakat yang lebih baik seperti membangun kebijakan yang pro terhadap rakyat, serta sistem kekuasaan yang memungkinkan adanya suatu otoritas untuk mengatur kehidupan masyarakat secara umum dan bukan tujuan orang perorangan. Dalam skripsi ini menggunakan metode deskriptif yang memberikan gambaran mengenai situasi atau kondisi yang terjadi di lapangan dengan menggunakan analisa kualitatif. Perbedaan penelitian ini dengan penelitian sebelumnya adalah studi tentang perilaku pemilih dikhususkan pada pemilih di lingkungan Perkebunan.

Berdasarkan latar belakang masalah di atas, tulisan ini dibuat untuk mengkaji lebih dalam seputar petani dan politik di Dusun Curah Macan, Desa Kalianyar, Kecamatan Ijen, Kabupaten Bondowoso.

\section{METODE PENELITIAN}

Dalam penelitian ini metode yang digunakan adalah metode penelitian kualitatif. Lokasi penelitian ini adalah di Dusun Curah Macan, Desa Kalianyar, Kecamatan Ijen, Kabupaten Bondowoso, Jawa Timur. Penelitian ini menggunakan teknik pengumpulan data berupa indept interview dan studi pustaka dimana pengumpulan data-data sekunder yang berhubungan dengan penelitian juga dilakukan. Selain itu penelitian ini juga menggunakan observasi, yaitu suatu cara pengumpulan data dengan melakukan pengamatan secara langsung. 


\section{HASIL DAN PEMBAHASAN}

\section{Politik dan Penguasaan Lahan}

Persoalan politik dan penguasaan lahan selalu menjadi hal yang menarik untuk dibicarakan. Penguasaan lahan tidak dapat dilepaskan dari kebijakan peerintah di bidang lahan, terutama dalam rangka mendukung kepentingan para penguasa. Kebijakan yang diterapkan oleh pemerintah bertujuan untuk menentukan struktur penguasaan lahan dan kelembagaan yang terbangun. Pada masa penjajahan, pemerintah kolonial sangat berkepentingan terhadap penguasaan lahan. Maka dari itu, kemudian pemerintah kolonial bekerja sama memanfaatkan golongan feodal yang ada untuk mengeksploitasi lahan masyarakat dengan cara memanfaatkan dan mempergunakan aturan yang sebelumnya diterapkan oleh Raja, seperti dalam penerapan pajak, upeti dan wajib kerja. Untuk lebih memudahkan manajemen pengaturan seperti dalam penarikan pajak dan wajib kerja tersebut, pemerintah kolonial Belanda memperkenalkan sistem komunal di Jawa. Dengan sistem komunal ini, pengaturan pajak, upeti, dan wajib kerja dapat dikoordinasikan melalui tingkatan pemerintahan yang telah terbangun.

Seiring berjalannya waktu banyak hal kemudian terjadi. Sistem penguasaan lahan yang dulu dijalankan oleh pemerintah kolonial Belanda perlahan mulai berubah. Setelah Indonesia merdeka, penguasaan lahan justru beralih dijalankan oleh pihak pemerintah Indonesia sendiri kala itu. Kata "dijalankan" disini bukan bermaksud negatif, melainkan justru ada keinginan dari pemerintah untuk menekan berbagai permasalahan agraria pada saat itu. Salah satu upaya yang dilakukan oleh pemerintah pada saat itu adalah dengan menetapkan Undang-Undang Pokok Agraria/UUPA. (UU No. 5 Tahun 1960). Undang-undang Pokok Agraria ini menempatkan hukum adat sebagai dasar utamanya. Landasan pokok dari UUPA meliputi: (a) fungsi sosial dari tanah, (b) penguasaan bersama, (c) asas nasionalisme, (d) larangan pemilikan lahan melampaui batas, (e) pencegahan monopoli atas tanah, dan (f) pengaturan hukum atas tanah. Berdasarkan dengan kebijakan pemerintah tersebut, politik penguasaan lahan juga dilaksanakan di beberapa daerah sampai saat ini. Salah satunya adalah di Dusun Curah Macan, Desa Kalianyar, Kecamatan Ijen, Kabupaten Bondowoso.

\section{Penguasaan lahan Pasca Orde Baru}

Penguasaan lahan di Dusun Curah Macan pasca orde baru dilakukan oleh orang-orang yang mempunyai jabatan di desa atau yang mempunyai pengaruh besar di Dusun Curah Macan. Hal ini seperti yang diungkapkan oleh ketua RT Dusun Curah Macan yaitu Pak Y, "Kalau dulu masih jamannya Gusdur belum bayar, yang paling lebar saya akui punya saya sendiri." (Wawancara dengan Pak Y Pada 26 Maret 2019), dari kutipan tersebut menggambarkan bahwa beliau mengakui jika dulunya pasca Orde Baru beliau merupakan orang yang paling banyak menguasai lahan di Dusun Curah Macan. Saat itu masyarakat cenderung dibebaskan untuk melakukan pembukaan lahan sendiri. Pembukaan lahan dilakukan dengan cara paksa meski ada pelarangan dari Pihak Perhutani. 
Pada masa pemerintahan Abdurrahman Wahid tahun 1999. Salah satunya kelompok penguasa lahan yang cukup dikenal di Bondowoso adalah kelompok Pagar Nusa. Pagar Nusa merupakan kelompok persilatan yang berada di bawah naungan Nahdlatul Ulama (NU). Pada awalnya tujuan dari kelompok ini hanya ingin memberantas kemungkaran dan kemaksiatan di desa selain isu ilmu hitam yang juga meresahkan warga desa. Namun organisasi ini lambat laun juga melakukan penguasaan lahan-lahan Perhutani di Dusun Curah Macan. Meski sebagian masyarakat mendukung keberadaan organisasi Pagar Nusa namun sebagian yang lain merasa terganggu. Hal ini juga dipicu kecemburuan dalam penguasaan lahan Perhutani. Seorang warga dusun menyampaikan bahwa saat akan menguasai lahan, umumnya mereka datang berbondong-bondong sehingga pihak Perhutani tidak berdaya untuk melarang. Sebagaimana kutipan berikut,

"Ya kan rame... Pagar Nusa datang satu pick up, ya.. gak berani polisi hutannya. Mau gimana lagi masa orang segitu banyak mau dihadapi ya mikir-mikir perhutaninya, akhirnya dibiarkan. (hasil wawancara Pak D, 27 Maret 2019).

Hal lain yang membuat timbulnya kecemburuan warga dusun adalah kenyataan bahwa umumnya anggota pagar nusa yang menguasai lahan di Dusun Curah Macan bukanlah penduduk Dusun Curah Macan melainkan dusun dusun di bawah. Sebagaimana kutipan berikut,

"Itu yang datang satu pick up bukan orang sini. Datang dari bawah, orang bawah. Ya kalau orang sini ya diam aja. Ndak ada yang berani. (wawancara dengan pak $\mathrm{D}$, 27 Maret 2019).

Penguasaan lahan oleh Pagar Nusa ini tidak berlangsung lama. Setelah Presiden Abdurrahman Wahid lengser dari jabatannya sebagai Presiden RI, kelompok Pagar Nusa pun juga turut menurun aktivitasnya. Selama ini menurut informasi dari beberapa warga, kelompok Pagar Nusa tersebut berafiliasi atau mempunyai jaringan dengan pemerintah sertai partai politik, sehingga ketika Presiden Abdurrahman Wahid lengser dari jabatannya mereka pun juga secara drastis berkurang aktivitasnya. Khususnya di dusun Curah Macan kelompok Pagar Nusa ini berafiliasi dengan Partai PKB (Partai Kebangkitan Bangsa).

Sementara itu, orang-orang yang dulunya menjadi bagian dari Pagar Nusa kini ada yang kembali ke daerah asalnya masing-masing dan bagi yang masih merupakan bagian dari warga bertransformasi menjadi petani di dusun Curah Macan. Mereka tentunya bukan petani biasa seperti sebagian masyarakat dusun Curah Macan, melainkan petani kaya yang mempunyai banyak lahan yang mempekerjakan banyak orang di sawah atau ladang.

\section{Perubahan Penguasaan Lahan}

Seiring berjalannya waktu sistem penguasaan lahan pun perlahan-lahan mulai berubah. Dengan adanya peraturan di PTPN 12 (Perkebunan Nusantara) serta Perhutani di Kecamatan Ijen, maka sistem penguasaan lahan yang dulunya begitu marak dilakukan kali ini dibagi menjadi 2 sistem agar menjadi lebih stabil, yakni sistem sewa lahan dan sistem sharing. 
Untuk dapat menggarap lahan petani di desa Kalianyar ini diharuskan untuk mengikuti aturan dari pihak PTPN dan Perhutani.

Penguasaan lahan pada PTPN 12 menggunakan sistem sewa. Jika para petani ingin membuka lahan maka harus mengajukan permohonan sewa lahan terlebih dahulu kepada PTPN 12 sebesar Rp. 4.200.000 per hektarnya. Seperti apa yang disampaikan oleh Pak M, selaku Sekertaris Desa Kalianyar bahwa:

"Untuk sistem sewa lahan, memang disini memakai sistem sewa lahan. Kalau ingin membuka lahan itu harus membayar uang sewa terlebih dahulu ke pihak PTPN sebesar Rp. 4.200.000 per hektarnya dan itu hanya untuk satu tahun"; (Wawancara dengan Pak M pada 26 Maret 2019).

Pihak PTPN hanya mengizinkan warga untuk menanam bibit tanaman sayur dan yang sejenisnya. Umumnya petani yang menyewa lahan di PTPN 12 adalah buruh atau karyawan PTPN 12. Beberapa petani yang ditemui di lapangan adalah mandor perkebunan dan istri-istri mandor yang juga merangkap menjadi petani kubis dan kentang.

Sementara itu, untuk penguasaan lahan Perhutani relatif lebih murah yakni sebesar 2 hingga 3 juta rupiah dalam setahun. Namun Perhutani masih memberikan syarat yakni petani harus bisa menjaga pohon-pohon tegakan milik Perhutani. Sebagaimana dalam kutipan berikut,

"Kalau Perhutani memang lebih murah 2 sampai 3 jutaan perhektarnya, tapi lihat luasan lahannya, Cuma ada syaratnya yaitu harus nanam pohon tegakan, nah pohon yang sudah ada dak boleh ditebang. (wawancara dengan Pak Y, 27 Maret 2019).
Selain itu, di lahan Perhutani petani mengenal peristirahatan lahan. Jadi, setelah para petani diizinkan untuk menanam dan panen, tanah tersebut tidak boleh ditanami apa-apa selama beberapa bulan. Hal ini juga terkait dengan keterbatasan akses air di lahan PTPN maupun Perhutani. Selain bahwa ini adalah strategi petani agar tidak merugi.

Sistem penguasaan lahan pada Perhutani juga dikenal dengan "sharing". Sistem ini sebenarnya merupakan sistem membagi keuntungan antara petani yang telah memanfaatkan lahan Perhutani dan pihak Perhutani. Berdasarkan penuturan Pak D yang adalah ketua LMDH petani seringkali mangkir dari membayar sharing jika kewajiban sharing ini dilakukan setelah panen. Petani sering beralasan bahwa hasil panennya kurang baik sehingga mereka menolak membayar sharing. Seiring berjalannya waktu, akhirnya pihak perhutani dengan dibantu LMDH akhirnya berhasil mengumpulkan kewajiban membayar sharing di awal masa tanam. Pembayaran itu dilakukan pada ketua LMDH dan kemudian disetorkan pada Perhutani.

\section{Politik dan Petani: Preferensi Politik Petani di masa lalu dan sekarang}

Berbicara mengenai preferensi politik tentu tidak lepas dari masyarakat dan kesejahteraan petani. Banyak faktor yang menyebabkan preferensi politik itu dinamis dari waktu ke waktu. Antara lain persoalan agama, lalu kepercayaan masyarakat terhadap pemimpin yang peduliterhadap rakyat, ketegasan seorang pemimpin dan lain sebagainya. Jika mengenai persoalan agama tentu karena 
penduduk Indonesia mayoritas beragama Islam, maka faktor agama menjadi sangat penting dalam menentukan seorang pemimpin. Pemimpin yang beragama Islam diyakini dapat membimbing atau mengarahkan masyarakatnya menuju jalan yang benar. Asumsi ini tentunya masih berlaku hingga saat ini. Khususnya di dusun Curah Macan, Desa Kalianyar, Kecamatan Ijen, Kabupaten Bondowoso masyarakatnya cenderung masih percaya akan hal ini. Agama masih menjadi hal yang penting dalam memilih seorang pemimpin.

Selain agama, faktor lainnya yang berkaitan dengan preferensi politik adalah mengenai pemimpin yang peduli terhadap kesejahteraan rakyat atau sikap pro-rakyat. Banyak hal yang dilakukan guna dapat menarik simpati rakyat seperti membagikan sembako gratis, lalu membagi-bagi uang kepada rakyat dan lain sebagainya. Tentu saja hal ini dilakukan oleh para calon pemimpin kepada rakyat. Tidak hanya itu saja, bahkan ada juga yang sampai pagar halaman rumahnya harus dicat dengan warna tertentu agar dapat menggambarkan afiliasi politik dari warga tersebut.

Tahun 2019 menjadi tahun yang menarik untuk diperbicangkan. Pesta demokrasi 5 tahunan yang selalu menjadi perhatian di kalangan masyarakat ini sekarang terjadi lagi. Kali ini di dusun Curah Macan juga ikut meramaikan pesta demokrasi ini baik masyarakat kalangan bawah hingga kalangan atas yang juga terkadang ikut serta dalam pemilihan umum tersebut.

Masyarakat dusun Curah Macan melihat 2019 ini tidak terlalu fanatik atau mereka terkesan biasa saja menyikapi pemilihan umum ini. Meskipun banyak poster atau baliho yang dipasang disana, namun rata-rata dari mereka mengatakan bahwa mereka (caleg) yang dipajang diposter atau baliho itu bukan berasal dari dusun Curah Macan melainkan berasal dari daerah bawah yaitu dari Sempol, Pelalangan, Sukosari, dan sebagainya. Mereka yang hanya bekerja sebagai petani mengatakan bahwa mereka hanya mau memilih jika mereka kenal dengan caleg yang dicalonkan.

Melihat hal tersebut masyarakat cenderung agak lebih tertutup dalam menyikapi pemilu ini. Namun, ada salah satu warga yang mengatakan bahwa kebanyakan masyarakat disini dulunya pada pemilihan sebelumnya tahun 2014 jika mengenai partai politik lebih condong kepada PDIP (Partai Demokrasi Indonesia Perjuangan). Begitu pula dengan Calon Presidennya lebih kepada Pak Joko Widodo. Alasan mereka memilih itu tidak diungkapkan secara jelas. Beda halnya dengan petani $Y$ yang secara terang-terangan mengatakan bahwa beliau merupakan tim sukses dari partai politik. Bahkan beliau mendorong masyarakatnya untuk memilih salah satu paslon yang beliau pilih.

Sebagian informan yang ditemui mengatakan bahwadasarmerekamemilih presiden terkait dengan kesejahteraan mereka. Mereka merasa bahwa presiden yang baik adalah yang dapat membuat harga pupuk, obat-obatan dan bibit menjadi lebih murah dan terjangkau bagi mereka sehingga mereka dapat menjadi lebih sejahtera.

Selain itu, petani sangat memperhatikan harga jual produk mereka. Sebagian mereka mengatakan bahwa jika mereka sangat kecewa jika 
pemerintah tidak dapat melindungi harga di kalangan petani. Pak K mengatakan:

"Kalau saya kok pingin nyoba ganti ya... pingin tahu kalau presidennya ganti apa enak apa ndak gitu ke petani. Soalnya kalau saya lihat itu kok, harga bibit, pupuk dan obat itu kok masih mahal ya... belum lagi orang tani ini bingung.. sudah panen bagus harga turun... pas gimana, pemerintah ini gimana ya.." (wawancara dengan pak K, 28 Maret 2019).

Hal ini menunjukkan bahwa preferensi politik petani sangat terkait dengan keseharian petani yang bergulat dengan pupuk, bibit dan obat serta naik turunnya harga komoditas yang dihasilkan. Masyarakat Dusun Curah Macan sendiri nampaknya tidak terlalu fanatic terhadap tokoh politik tertentu. Kesehariannya saat itu (saat penelitian berlangsung) tidak diwarnai dengan perdebatan tentang pemilihan presiden yang pelik meskipun saat itu musim kampanye. Keseharian petani lebih banyak diwarnai dengan kesibukan dan pembicaraan tentang panen kubis dan harga pasaran kubis.

\section{KESIMPULAN}

Perubahan ekonomi adalah suatu proses moral sekaligus material. Tidak bisa dipungkiri bahwa dampaknya sangat terasa. Tidak hanya berdampak dari segi pendapatan dan produksi, tapi juga pada segi identitas, aspirasi, serta otoritas. Persoalan mengenai politik dan penguasaan lahan selalu menjadi hal yang menarik untuk dibicarakan. Penguasaan lahan tidak dapat dilepaskan dari kebijakan pemerintah di bidang lahan, terutama dalam rangka mendukung kepentingan para penguasa.
Dalam lingkup wilayah pertanian tentu ada pihak-pihak yang mempunyai pengaruh besar terhadap kehidupan masyarakat dusun Curah Macan khususnya pada masyarakat yang bekerja sebagai petani. Dari pengaruh itu kemudian bisa diketahui bahwa ada keterkaitan dengan sistem yang dijalankan dalam sistem pertanian di dusun Curah Macan ini dan selanjutnya tentu saja bagaimana cara pandang masyarakat dusun Curah Macan terhadap seorang pemimpin. Cara pandang ini umumnya didasarkan pada keterkaitan terhadap kesejahteraan petani itu sendiri. Pemimpin atau presiden idaman bagi mereka adalah presiden yang mampu menurunkan harga bibit, obat dan pupuk dan mampu menjaga kestabilan harga produk pertanian yang mereka hasilkan. Hal ini mereka percayai akan meningkatkan kesejahteraan petani. Hal ini pula yang mereka percayai sebagai pemimpin ideal bagi mereka.

\section{DAFTAR PUSTAKA}

Budiardjo, Miriam. 1992. Dasar-Dasar Ilmu Politik. Jakarta: PT Gramedia Pustaka Utama.

Hefner, Robert W. 1999. Geger Tengger: Perubahan Sosial dan Perkelahian Politik. Yogyakarta: LkiS.

Liando, Daud M. 2016. Pemilu dan Partisipasi Politik Masyarakat (Studi Pada Pemilihan Anggota Legislatif dan Pemilihan Presiden dan Calon Wakil Presiden di Kabupaten Minahasa Tahun 2014). Jurnal LPPM Bidang EkoSosBudKum, 14-28.

Maksum, Ali. 2015. Politik Identitas Masyarakat Tengger dalam Mempertahankan Sistem Kebudayaan Dari Hegemoni Islam Dan Kekuasaan. el Harakah Vol. 1, 18-35. 
Rachmat, Muchjidin; Muslim, Chaerul. 2012. Dinamika Penguasaan Lahan dan Kelembagaan Kerja Pertanian. Penguasaan Lahan dan Pragmentasi Lahan, 94-95.

Sastroatmodjo, Sudijono. 1995. Perilaku Politik. Semarang: IKIP Press.

Tiffany, C.R. 2008. Preferensi Politik (Studi Tentang Perilaku Pemilih di Lingkungan IV Kelurahan Perkebunan Sipare-Pare pada Pemilihan Kepala Daerah (Bupati).
Undang-Undang No. 5 Tahun 1960 Tentang Peraturan Dasar PokokPokok Agraria.

Zainuddin, A.Rahman. 1996. "Antara Politik dan Moral", Jakarta: PT Gramedia Pustaka Utama, Jurnal Ilmu Politik, 16, h. 3. 